\title{
LAND USE AND PLANNING IN RURAL AREAS (A CASE STUDY OF GIEDRAIČIAI SUBDISTRICT)
}

Jolanta VALČIUKIENĖ, Institute of Land Use Planning and Geomatics, Water and Land Management faculty, Aleksandras Stulginskis University, Lithuania. Address: Universiteto g. 10, LT - 53361 Akademija, Kauno distr., Lithuania, jolanta.valciukiene@asu.lt (corresponding author)

Virginija ATKOCEVIČIENÉ, Institute of Land Use Planning and Geomatics, Faculty of Water and Land Management, Aleksandras Stulginskis University, Universiteto 10, LT-53361, Akademija, Kaunas distr., Lithuania, virginija.atkocevičienė@asu.lt

Daiva JUKNELIENE், Institute of Land Use Planning and Geomatics, Faculty of Water and Land Management, Aleksandras Stulginskis University, Universiteto 10, LT-53361, Akademija, Kaunas distr., Lithuania, daiva.jukneliene@asu.lt

Edita JUOČYTÉ, Institute of Land Use Planning and Geomatics, Faculty of Water and Land Management, Aleksandras Stulginskis University, Universiteto 10, LT-53361, Akademija, Kaunas distr., Lithuania, editajuocyte@ gmail.com

\begin{abstract}
The rational use of land should be ensured, soil-friendly agricultural branches should be developed as well as attractive environment for work, living and resting in the countryside should be created in promoting rural development in Lithuania. Areas with favourable natural conditions have a high degree of economic activity, farm size, and economic development. However, not everywhere the natural conditions for the development of agriculture are favourable. The research was carried out in the Giedraičiai rural area of Molètai district, which deals with the factors influencing the use of land, the declared area of land, the problem of land abandonment. The methods of legal analysis, analysis of literature, analysis, comparison and aggregation of statistical data were used during the research. After the fulfilment of the analysis of the declared area of land during the period between the years 2012 and 2016, it was established that the area of agricultural land declared during the five years increased by 655 hectares, the number of farmers who declared agricultural land decreased by 104, and the number of declared parcels declined even to 1729. The process of the growing of farms is likely to occur. The area of abandoned land in Giedraičiai subdistrict reaches 300 hectares, the number of abandoned areas exceeds 800. Estimating the statistical data and solutions of the general plan of the Moletai district area preliminary solutions for the management of the territory of the Giedraičiai subdistrict for agriculture and rural development are being provided, i.e. it is planned to implement rural development land use planning projects for the management of farms, and to select a farmhouse farm site. To reduce the abandoned land areas, it is advisable to plan forests, expand the areas of meadows and natural pastures, apply organic farming and adapt the areas for recreation.
\end{abstract}

Keywords: land management, agricultural land, rural development, preliminary solutions.

\section{INTRODUCTION}

In the present-day agrarian state, rural areas are associated with the country's most important resource - the land. When analysing further, the village is associated not only with economic activity but also with the environment and development.

There are various "village" definitions found in the scientific literature. Although most authors speak different words, their main idea is the same. V. Ratkevičienè and E. Kocai (2013), analysing the socioeconomic status of Lithuanian countryside, describe the village as follows: "Lithuania's village is a historically territorial, and by 1945, and an administrative communal unit composed of homesteads (mostly farmsteads) and remaining settlements (villages with churches, small traditional townships, etc.) ".

According to Jonas Jasaitis, the village is characterized by the sparsely populated area where the majority of the population is employed in the agrarian sector. The village is referred to as the opposite to the city's territory, which is dominated by densely built-up areas, concentrating industrial enterprises, educational and cultural institutions, and providing a high level of social services (Jasaitis, 2014). Meanwhile, Dalia Vidickienè and Rasa Melnikienè interpret the village as a whole of the settlements that are fragmented throughout the state and lacking the organizational integrity necessary for the consistent implementation of rural policy measures, speaking about the classification of the Lithuanian region in the aspect of the rurality (Vidickienè et. al., 2008).

Strong rurality regions are located in the eastern and southern parts of Lithuania. Most of the regions in Lithuania are of intermediate rurality, followed by weak rurality regions. Semi urban and urban regions are concentrated in the

Copyright (C) 2017 The Authors. Published by Aleksandras Stulginskis University. This is an open-access article distributed under the terms of the Creative Commons Attribution License (CC-BY 4.0), which permits unrestricted use, distribution, and reproduction in any medium, provided the original author and source are credited. 
northern, western, middle and south-eastern parts of Lithuania (Fig. 1). The area under study of Giedraičiai subdistrict is located in the municipality of Moletai district, which is located in the intermediate rurality region.

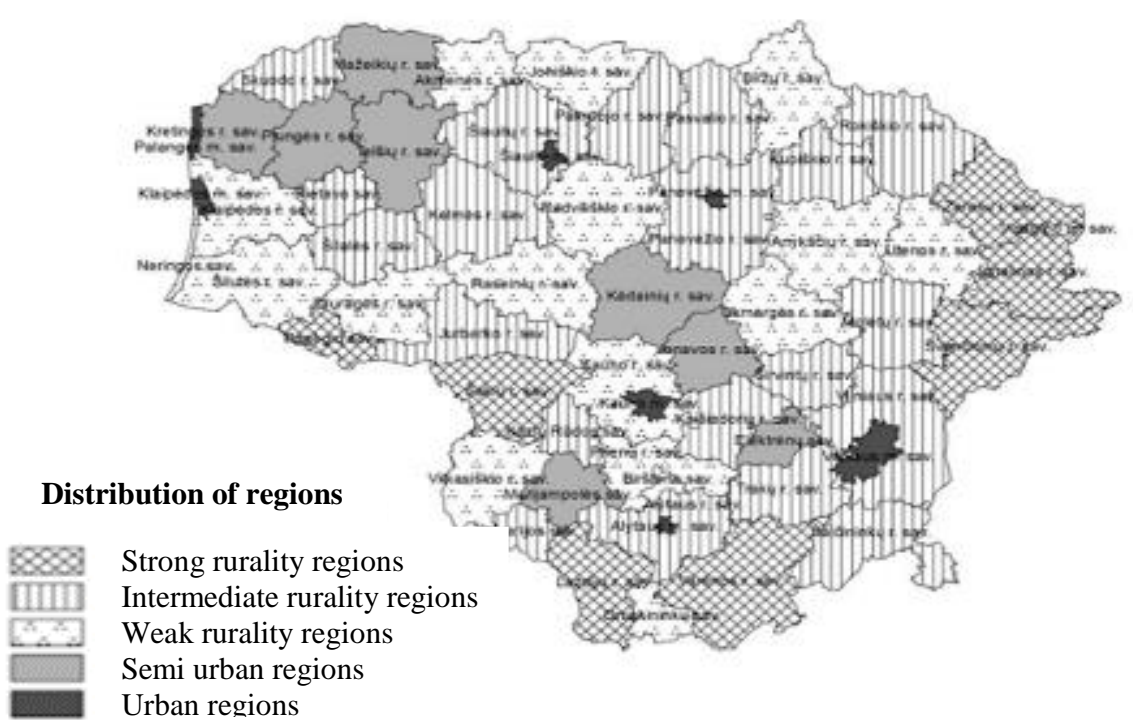

Figure 1. Lithuanian regions according to the integrated assessment of the rurality (Melnikienè et al., 2011).

The change in natural conditions determines the land suitability for economic activity. The increasing demand for food, feed, fiber and bio-energy increases land use and seeks to find compromises between different land uses and the preservation of ecosystems. By seeking solutions, adapting the areas of economic activity to changing climatic conditions requires novelty and modern technology (Zabel et al., 2014). The use of agricultural land, forestry and other land plays a key role in the food industry and promotes sustainable agricultural development. The quality of human life is directly dependent on land resources (Smith et al., 2014).

In order to target the purposeful land use it is important to properly choose the right branch of economy to develop. While selecting agricultural land and crops soil properties should be taken into account in order to ensure rational land use. More intensive land use would be achieved if better use of crop areas and the pastures for the development of dairy farming and pedigree cattle breeding were used (Aleknavičius et al., 2011).

P. Aleknavičius and others (2014), analysing the problems of the use of agrarian areas and their solution in Lithuania, indicate that land use is affected by the privatization of the assets of agricultural enterprises, the reorganization of enterprises into smaller units, the restoration of ownership rights to land, a limited budget for the reconstruction of drainage systems, the deterioration of agricultural land use improvement, as well as financial support from European Union funds. The projects implemented and the activities of farmers are regulated by legal acts.

The Law on Agriculture, Food Industry and Rural Development of the Republic of Lithuania states that the purpose of agricultural, food and rural development policy is to rationally use land on the basis of land management and agrotechnical measures as well as to preserve and increase soil productivity by means of land reclamation and other measures (Lietuvos ..., 2008). Meanwhile, the Law on Land of the Republic of Lithuania regulates that landowners and other users must use land in accordance with its main purpose and use, rational use and conservation of land, forest, water, mineral resources and other natural and recreational resources (Lietuvos ..., 2004).

The approved General plan of the territory of the Republic of Lithuania (2002) is the main planning document regulating the long-term strategy of the use and management of the territory of the country. A general plan is the general strategy and priorities for the use and protection of the territory of the country. Seven different agrarian potential zones have been identified for the management of agrarian areas in the country (Table 1).

Table 1. Differentiation zones of agrarian areas (Lietuvos..., 2002).

\begin{tabular}{|c|c|c|c|c|c|c|c|}
\hline Zone No. & I. & II. & III. & IV. & V. & VI. & VII. \\
\hline $\begin{array}{c}\text { Name of the } \\
\text { zone }\end{array}$ & $\begin{array}{c}\text { South- } \\
\text { eastern } \\
\text { Lithuanian } \\
\text { zone }\end{array}$ & $\begin{array}{c}\text { Baltic hilly } \\
\text { zone }\end{array}$ & $\begin{array}{c}\text { Aukštaitija } \\
\text { and Dzūkija } \\
\text { Plateau } \\
\text { zone }\end{array}$ & $\begin{array}{c}\text { Central } \\
\text { Lithuania } \\
\text { zone }\end{array}$ & $\begin{array}{c}\text { Žemaitija } \\
\text { Plateau zone }\end{array}$ & $\begin{array}{c}\text { Žemaitija } \\
\text { hilly zona }\end{array}$ & $\begin{array}{c}\text { Nemunas } \\
\text { downstream } \\
\text { and the } \\
\text { Lowland zone }\end{array}$ \\
\hline $\begin{array}{c}\text { Area of the } \\
\text { zone }\left(\mathrm{km}^{2}\right)\end{array}$ & 772 & 1239 & 692 & 2426 & 647 & 242 & 512 \\
\hline
\end{tabular}

The largest areas of productive land occupy the Central Lithuania zone. South-eastern Lithuania is characterized by unfavourable farming conditions. The main task of the country's General Plan is to identify the appropriate specialization of agrarian activities in different regions, taking into account the prevailing natural conditions. The area of Giedraičiai subdistrict falls into the Baltic hilly zone, which is characterized by unproductive and ecologically sensitive lands. In this zone, it is advisable to specialize in grass-crop cultivation. 
Although a large part of the population of Lithuania is working in the agrarian sector and the use of land is intense, the problem of abandoned land is still relevant. Every year the area of abandoned land in the country is intensively reduced: according to the accounting data of January 1, 2017, 64173.94 ha of the abandoned lands were registered in the country, which is almost six thousand more hectares than last year.

When dealing with scientific literature, various author's opinions are encountered in the subject matter of abandoned lands. This topic was discussed by G. Kuliešis and others (2011), G.Ribokas (2008), V. Bielinskas (2016). In the Rural Development Program (hereinafter - RDP), abandoned land is defined as the abandoned agricultural land that has not been used for agricultural activities for three consecutive years (Kuliešis et al., 2010).

The problem of abandoned lands is relevant not only in Lithuania but in different countries of Europe and the world as well. Different definitions of abandoned land are found in foreign literature, but their significance is the same: land is no longer used for agricultural activity. According to Pointereau (2008) and Moravec (2007), the abandonment of land is a transition from intensive land use to less intense. Meanwhile, Coppola (2004) describes abandoned land as being no longer used in the production process.

According to J.M. Rey Benayas et al. (2007), land abandonment is a complex, multifaceted process that influences the economic and social environment. Three types of causes of land abandonment are distinguished. The first type includes ecological causes: soil erosion, relief, soil composition, climate, and its changes. The second type includes economic and social causes, which include market promotion, migration, rural depopulation, technological development, land management system and security, agricultural characteristics and urban development. The third type of land abandonment refers to not suitable agricultural systems and management that leads to soil degradation (Benayas et al., 2007).

Different regions of Europe have different causes for land abandonment (Moravec, 2007). Each region develops only its characteristic agricultural direction, which causes various abandonment factors (historical, demographic, geographic, economic). In analysing the causes of land abandonment, the links between these factors are most often indicated, most of them predominantly together, not by one (Pointereau, 2008).

E. C. Rico and R. C. Maseda refer to geographic location and structural, social and economic factors as the reason for land abandonment. The structural factors involved are the size of land parcels and farms, irrigation systems and the distance to the centres of consumption. The indicated economic factors are the difference between labour costs and sales. Social factors include the age and education of farmers as well as financial resources (Rico et al., 2008).

J. Valčiukienè et al., (2016) cites the return of land to former owners in the course of the land reform as the reason for the abandonment of land. During the process, most of the land parcels returned were small, and people were not yet ready to carry out their economic activity there. At that time, the most important priority on the market was the profitability of agriculture, which resulted in farmers cultivating less fertile land being in a worse position than those working on more fertile land.

Even more efficient ways to reduce abandoned land areas would be achieved by applying appropriate solutions in suitable regions. In regions where fertile soils are predominant, it is appropriate to apply the development of agricultural activities. In infertile soils, it is advisable to plant forests and to grow energy crops. Compensation for land reclamation works and the provision of support and preferences for the management, improvement and use of abandoned land should be applied in all regions facing land abandonment problems.

The aim of the paper was to analyse the rural areas of the Giedraičiai subdistrict of Moletai district and to provide preliminary territorial management solutions for the example of an agricultural and rural development project.

Objectives: to study the trends of land use, farmers' farms development in Giedraičiai subdistrict; to carry out analysis of abandoned lands and to provide possibilities for their use; to prepare preliminary land management solutions in the area under study.

\section{METHODOLOGY OF RESEARCH AND MATERIALS}

The article is based on methods of legal and scientific literature, analysis of statistical data, interviews, comparisons and generalization methods. Data collected for the survey were collected from: State Enterprise Center for Agricultural Information and Rural Business, Giedraičiai subdistrict and National Land Service under the Ministry of Agriculture. During the interview, the data on land use in the Giedraičiai subdistrict were collected. Based on the cartographic data set, solutions for territory management were provided.

\section{RESULTS AND DISCUSSION}

There were 19233 inhabitants in the Moletai district municipality in 2015. There were 14 inhabitants per square kilometer. Molètai are characterized by abundance of protected areas. There are 5 state reserves, 8 protected natural heritage sites. The district's area includes part of the Labanoras and Asveja regional parks.

The use of land in Moletai district is determined by natural conditions, limited possibilities for agricultural development, and peculiarities of population distribution. Table 2 gives a comparison of the composition of land utilities in Molètai district, Utena county and the Republic of Lithuania.

In the country, the largest part of land utilities was occupied by agricultural land - 3421526 ha, of which 321464 ha belong to Utena county. In the Moletai district municipality, the largest area was occupied by agricultural land, and the smallest - by roads. Taking into account such relatively large areas of agricultural land, in the district it is expedient to develop agriculture, combining intensive and extensive farming and proper use of recreational areas. 
Table 2. Data on land utilities for January 1, 2017 (www.nzt.lt)

\begin{tabular}{|c|c|c|c|c|c|c|c|}
\hline Object & Total area, ha & $\begin{array}{c}\text { Agricultural } \\
\text { land, ha }\end{array}$ & Forests, ha & Roads, ha & $\begin{array}{c}\text { Built-up } \\
\text { territory, } \\
\text { ha }\end{array}$ & $\begin{array}{c}\text { Water } \\
\text { bodies, ha }\end{array}$ & $\begin{array}{c}\text { Other land, } \\
\text { ha }\end{array}$ \\
\hline $\begin{array}{c}\text { In the Republic } \\
\text { in total }\end{array}$ & 6528648.3 & 3421526.54 & 2178958.04 & 104773.47 & 236401.82 & 264465.49 & 322522.94 \\
\hline Utena county & 719135.55 & 321464.88 & 253865.47 & 10820.56 & 20717.84 & 53912.38 & 58354.42 \\
\hline $\begin{array}{c}\text { Molètai district } \\
\text { municipality }\end{array}$ & 136682.81 & 61009.08 & 43249.07 & 2292.13 & 4344.02 & 12630.46 & 13158.05 \\
\hline
\end{tabular}

In the Republic of Lithuania, according to the data of May 1, 2017, the area of land managed by farmers amounted to 1148165 ha, of which 126623 ha were land managed by Utena county farmers. In the Molètai district by May 1, 2017, 3212 farms with a total land area of 23821 ha (Table 3) were registered.

Table 3. Number of farms registered in the register of farmers and their land by May 1, 2017 (Data from the ŽUIKVC)

\begin{tabular}{|c|c|c|}
\hline Object & Number of farms & Total land area, ha \\
\hline Republic of Lithuania & 122611 & 1148164.94 \\
\hline Utena county & 13226 & 126623.52 \\
\hline Molètai district & 3212 & 23821.06 \\
\hline
\end{tabular}

Giedraičiai subdistrict is a structural subdivision of the Moletai district municipality administration located in the south-western part of the district. The area occupied by the municipality is 17500 ha, the population according to the data of the administration of the municipality is 2750 . Giedraičiai town, located on the west coast of the Lake Kiementas, is the centre of the subdistrict.

When analysing the concept of the General Plan of the Moletai district for the territory of Giedraičiai subdistrict, it was determined that the areas of influence of promising residential areas around the territory of Giedraičiai town are planned (Fig. 2).

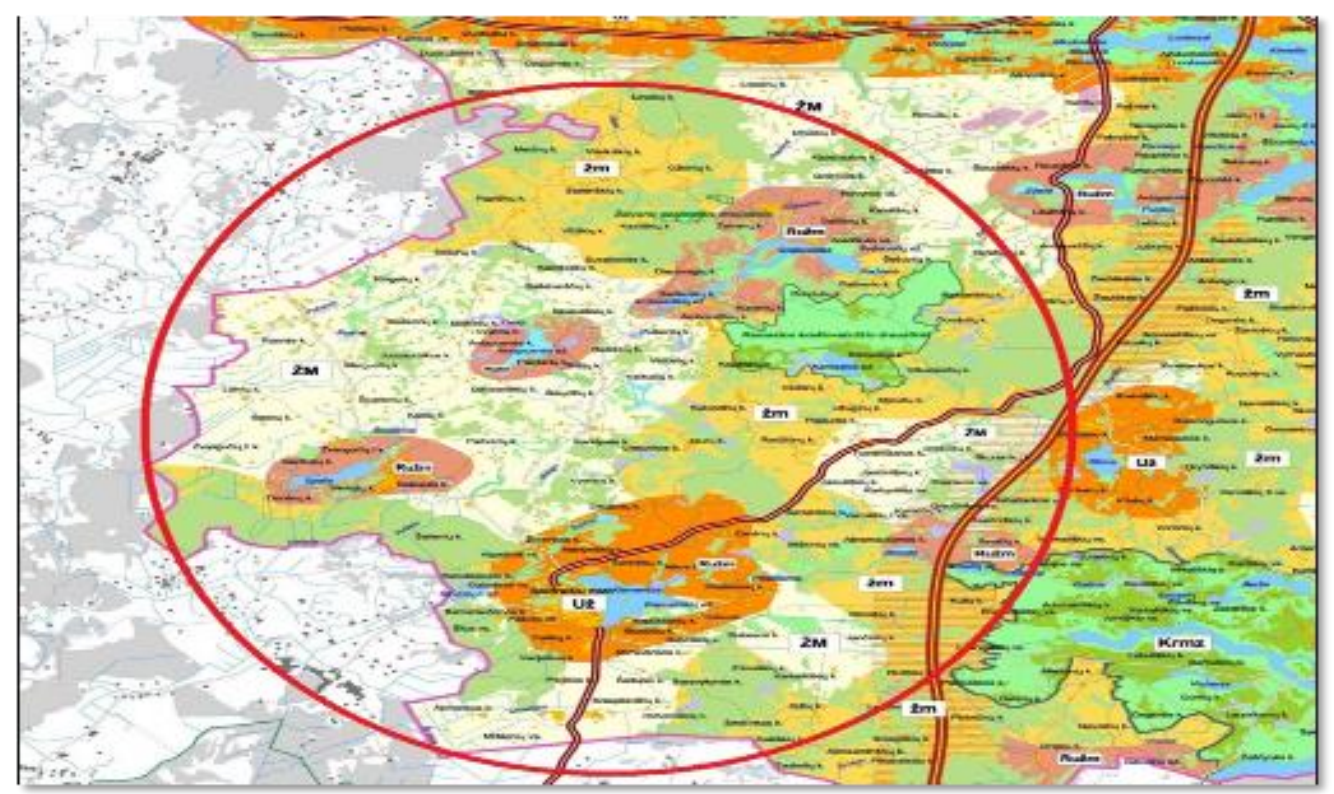

Figure 2. Use and functional priorities of the territory of Giedraičiai subdistrict (Molètai district general plan)

Around the lakes of Grabuostas, Ambraziškiai, Antapusnè and Spalis, recreational areas with the most valuable aesthetic resources are planned. In these areas, it is expedient to build recreation houses as well as tourism, services and entertainment structures. Forestry land predominates in northern, eastern and southwestern parts of Giedraičiai subdistrict. The southern and western parts of the subdistrict include intensive agricultural and forestry areas characterized by the cultivation of commercial agricultural production. In the remaining part of the territory, extensive forest and forest areas are planted near the forests. The peculiarity of this area is sustainable and organic farming. The general plan also outlines the prospective sites of the homesteads and the road network.

The territory of Giedraičiai subdistrict includes the areas of Žalvariai, Dūdènai, Giedraičiai and part of the Bijutiškiai cadastre vicinity. The average soil productivity score of the subdistrict is 30.4 . The soil productivity score varies considerably between parts of the territory. The prevailing soil granulometric composition is sand and sandy loam.

In the analysed territory of Giedraičiai subdistrict, due to the prevailing water bodies, protective zones and belts of water bodies dominate in the territory. In the area, also predominate electric and road protection zones. There is also a 
Molètai aerodrome in the territory of the Giedraičiai subdistrict, which has a protection and sanitary protection zone. The area under study is rich in cultural heritage objects located in subzones of physical impact protection and visual protection.

Moletai district falls into the location of natural handicaps and areas of heavy farming unfavourability. Farmers declaring agricultural land receive compensatory payments from European Union support for each hectare of land designated for agricultural purposes in order to compensate the beneficiaries for additional costs and loss of income suffered as a result of heavy natural handicaps to agricultural production. The measure of the Lithuanian Rural Development Program for 2014-2020 "Payments to farmers in areas with heavy natural handicaps" aims to support and preserve unfavourable for farming areas. In 2016, compensation payments of $73.6 \mathrm{EUR} / \mathrm{ha}$ were granted to areas with a high risk of unfavourability for farming and 55.2 EUR/ha of compensatory payments to areas with low unfavourability for farming. These measures promote the use of land in unfavourable for farming areas, preventing its abandonment. Existing rural development projects foresee that in infertile soils, it would be expedient to develop alternative activities, install pastures for long-term use, and plant the forests. After analysing 10 randomly selected farmers' farms in Giedraičiai subdistrict, it was estimated that from 2012 by 2016 the total area of declared agricultural land had increased by 655 ha. Meanwhile, the number of farmers decreased by 104, and the number of declared land plots decreased by 1729 . It is expected that during the analysed period, farms grew and their area under cultivation increased (Table 4).

Table 4. Declaration of agricultural land in Giedraičiai subdistrict in 2012 - 2016 (Interview Survey Data)

\begin{tabular}{|c|c|c|c|c|c|}
\hline Indicator / Year & $\mathbf{2 0 1 2}$ & $\mathbf{2 0 1 3}$ & $\mathbf{2 0 1 4}$ & $\mathbf{2 0 1 5}$ & $\mathbf{2 0 1 6}$ \\
\hline Total area of declared land, ha & 4712 & 4771 & 4942 & 5205 & 5367 \\
\hline Number of farmers & 531 & 503 & 476 & 448 & 427 \\
\hline Number of declared parcels & 4854 & 4250 & 3947 & 3534 & 3125 \\
\hline
\end{tabular}

The land used by farmers is not located rationally everywhere, plots are not compact, and not everyone has a good road network. Intensive farming is planned in the areas of productive soils (Fig. 3).

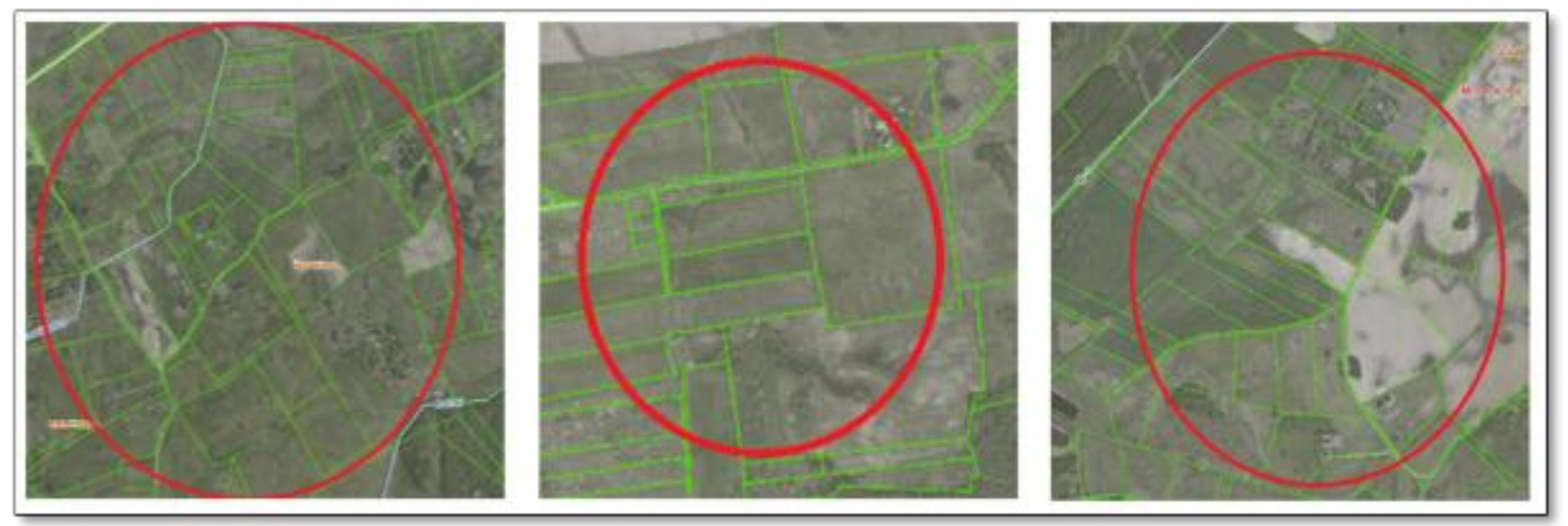

Figure 3. Planned intensive farming areas (Compiled by authors, based on www.regia.lt)

There are no large plots of land in the territory of Giedraičiai subdistrict that would encourage the development of intensive farming. Very often farmed areas are far away from each other. Such conditions do not allow farmers to work at their full capacity. In intensive farming areas, it would be beneficial to develop internal land management projects for rural development farms. During the fulfilment of projects, agro-plots and their rational use are planned. Created crop rotation plans would allow planning the composition of agricultural crops and their rotation, taking into account the direction of economic activity and environmental protection requirements. Farmland internal land management projects will provide farmers with information about the characteristics of their cultivated land, the necessary improvement measures, the crop structure and the appropriate crop rotation type.

The Rural Development Land Management Project is a locality level specific territorial planning land management document prepared in the rural areas to plan a complex change in the composition of land utilities, forest planting, and to formulate land holdings in agriculture and alternative activities. Based on these projects, the most suitable place for the farmer's farmstead is chosen.

The development of rural areas depends on population changes. Promoting the growth of the population as well as the involvement of young people in rural economic activity, the European Union supports the setting up of young farmers. To help young farmers to set up, the rural development projects of land management would be prepared for the formation of a farmstead site. In the territory of Giedraičiai subdistrict, the planned favourable sites for the formation of farmers' farmsteads are presented in Fig. 4. 


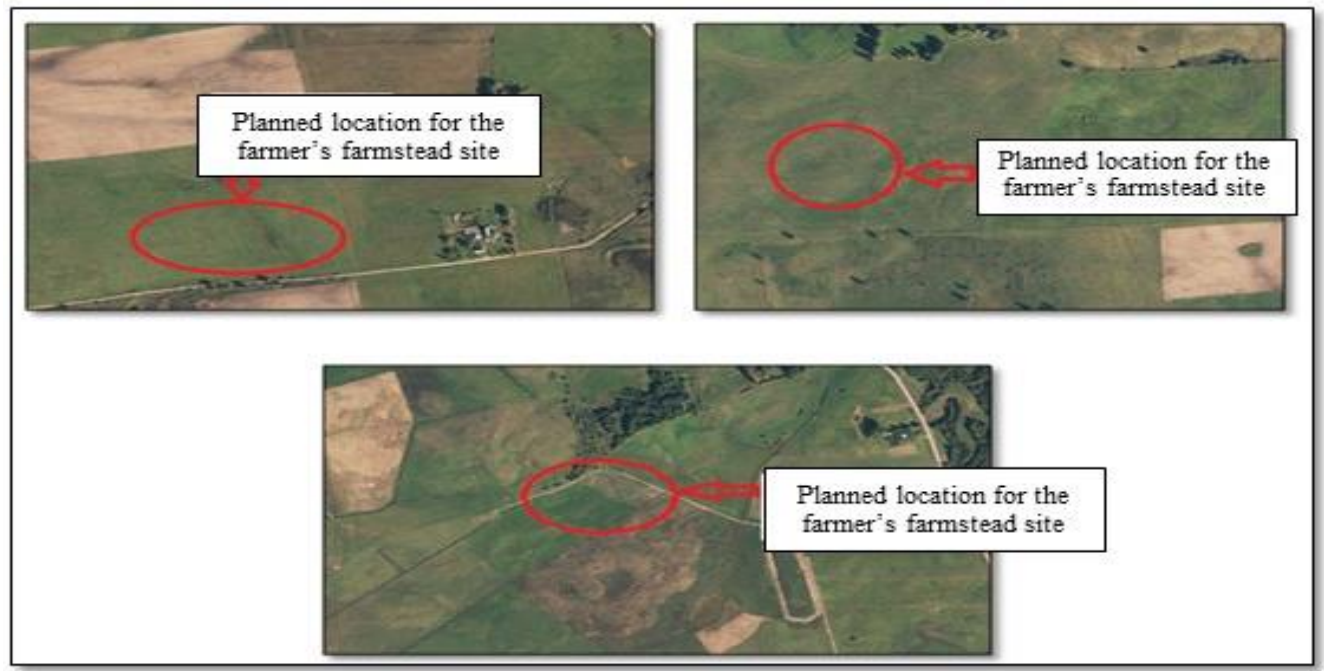

Figure 4. Planned location for the farmer's farmstead site (Compiled by authors, based on www.regia.lt)

The analysed farmstead sites are selected according to the terrain in higher, more dried areas of low productivity and sandy soils. Farmstead sites are designed in such a way that it would be convenient to get to the farmer's farmland. Also considering the site of a farmer's farmstead, it is taken into account that there would be other homesteads nearby in order to facilitate the installation of sewerage and water supply systems more quickly and easier. Formation of farmsteads closer to one another also reduces the costs of building different engineering communications.

Unfertile soils are characteristic to areas planned for extensive farming. In such areas, it would be beneficial to conduct non-traditional economic activities that would adapt to the existing soil properties (Fig. 5).
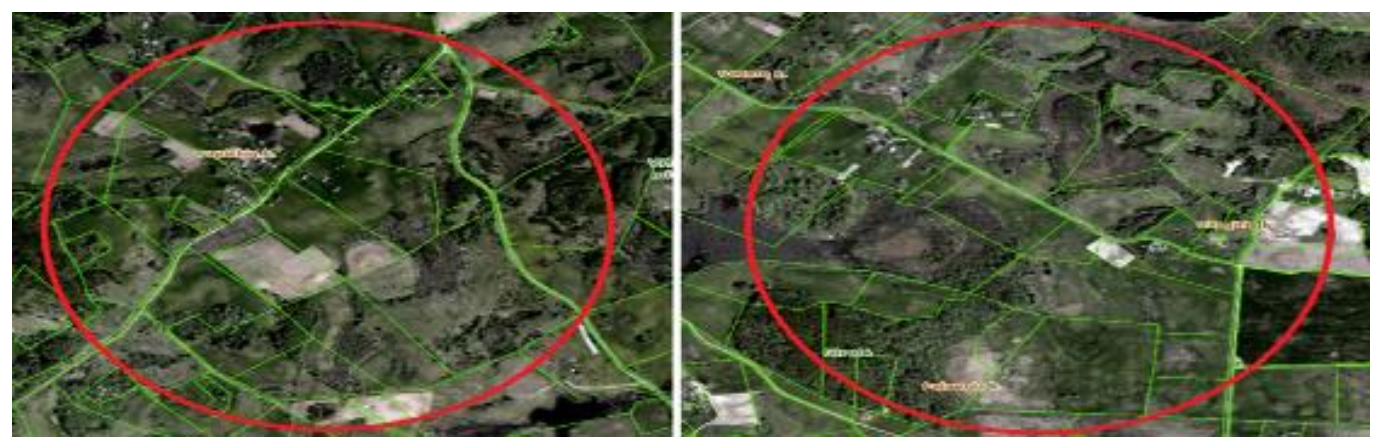

Figure 5. Planned extensive farming areas (compiled by authors based on www.regia.lt)

Giedraičiai subdistrict is a passive land for rural development measures, as there is one organic farm in the whole subdistrict. In the period between the years 2012 and 2016, the area of land declared by farmers has increased and the number of farmers has decreased, reflecting the ongoing process of the growing of farms. Development measures are planned for the development of agriculture and improvement of the quality of rural population (Fig. 6).

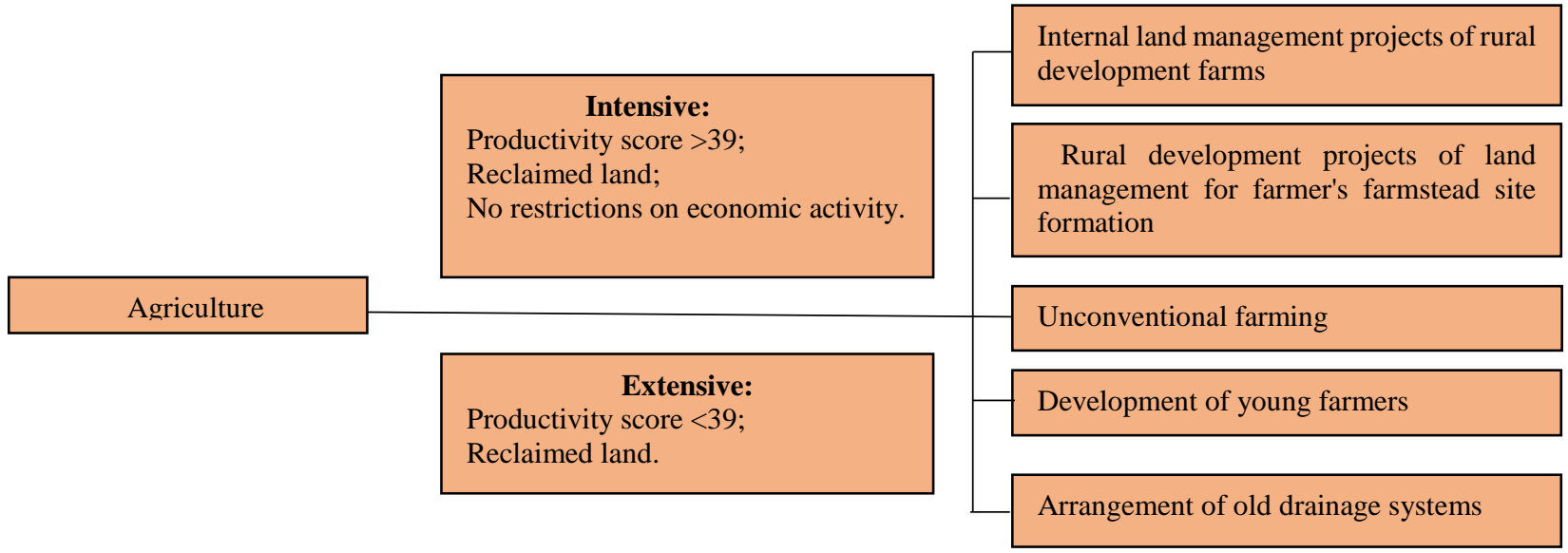

Figure 6. Planned measures for agricultural development (compiled by authors)

A large area of abandoned lands is prevailing in Giedraičiai subdistrict. There are 831 abandoned land parcels in the subdistrict. The total area of abandoned land is 296, 91 ha. In order to determine the causes of land abandonment in 
the analysed area and to provide measures for solving this problem, to analyse abandoned land areas in the eastern part of the sub-district (Fig. 7).

In order to determine the causes of land abandonment in the analysed area, and to provide measures for solving this problem, abandoned land areas in the eastern part of the subdistrict were analysed (Fig. 7).

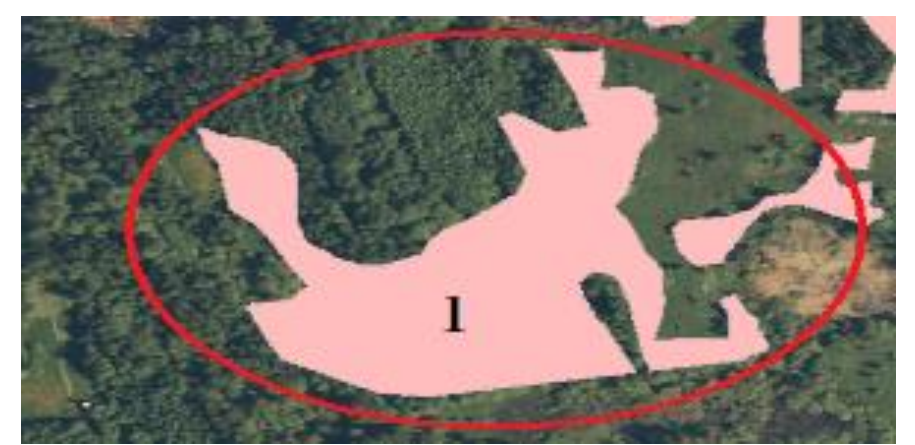

Figure 7. Abandoned land massive No. 1 (Compiled by authors based on www. žis.lt)

The area of the analysed abandoned land is situated in Giedraičiai subdistrict, Bitenai village. The western part of the territory is interspersed with the forest. The eastern part borders with meadow or pasture. In non-fertile lands, unattended agricultural land is overgrown with woody plants and eventually becomes forests. In this abandoned land area it would be advisable to plant the forest, since the forest borders on three sides. In the adjacent meadow or pasture, trees and shrubs should be cut down to avoid land abandonment.

In order to find solutions to reduce abandoned land, the prevailing vegetation, soil properties, relief, and land suitability for mechanized work should be evaluated. In order to reduce land abandonment, it is necessary to conduct economic activity on such land. The use of land reclamation and agrotechnical measures would be appropriate for the cultivation of abandoned land areas. The following measures of land management are recommended: land use for crops, meadows and pastureland, land use for afforestation, and the leaving of land for renaturalization (Aleknavičius et al., 2016).

Having analysed the abandoned land in the territory of Giedraičiai subdistrict, one can distinguish the reasons for the emergence of abandoned lands, as well as the possibilities for its usage (Fig. 8)

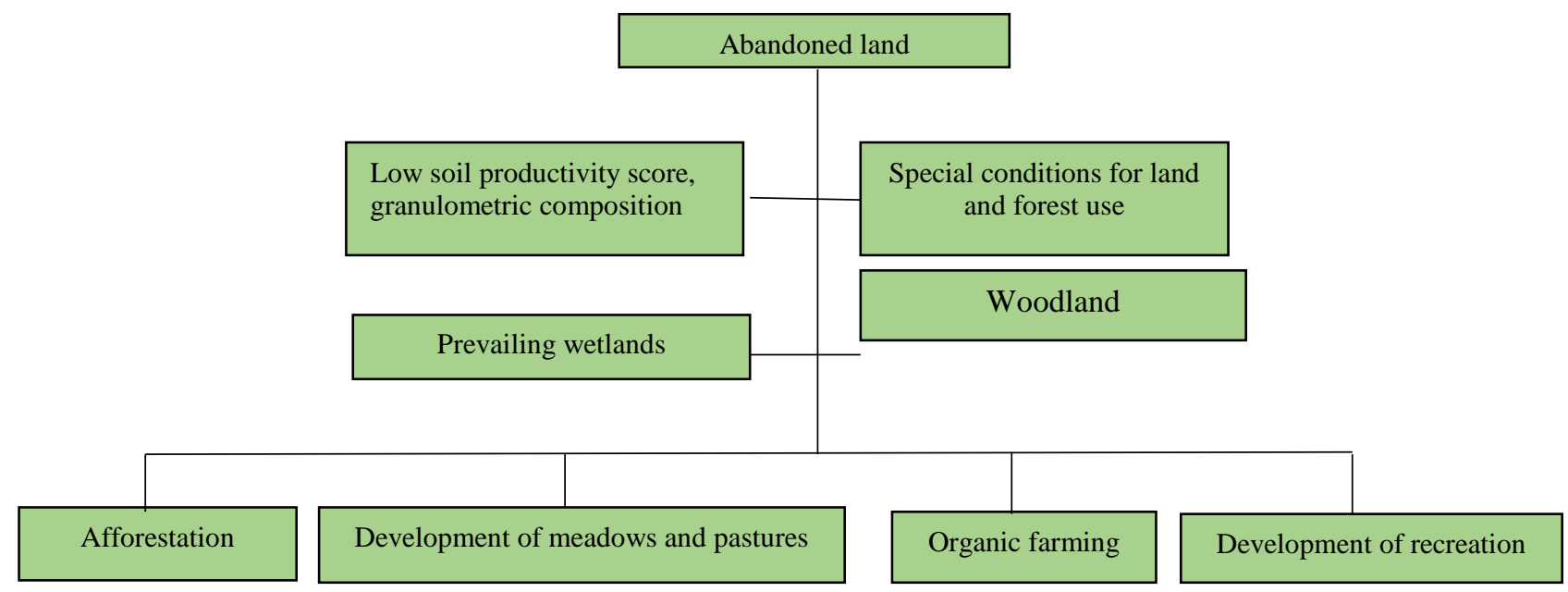

Figure 8. Reasons and usage possibilities of land abandonment (Compiled by the authors)

The following measures are planned in the area of Giedraičiai subdistrict: afforestation, development of meadows and pastures, application of organic farming, and recreation development.

Summing up the use of the land of Giedraičiai subdistrict it can be argued that natural conditions, soil fertility, protection zones allocated to water bodies, abundance of abandoned areas create unfavourable conditions for the development of intensive farming. However, the beautiful landscape, the skills of the intelligent people and the rural development measures encourage the development of alternative activities.

\section{CONCLUSIONS}

1. The decline in rural population, changes in the areas of land utilities, the lack of young farmers in rural areas, the abandoned land areas, and low productivity areas affect rural and agricultural development. The most problematic areas are found in the region of Eastern Lithuania.

2. After analysing the land use of Giedraičiai subdistrict, it has been established that the area of declared agricultural land increased by 655 ha, the number of farmers declaring agricultural land decreased by 104, and the number of 


\section{Proceedings of the $8^{\text {th }}$ International Scientific Conference Rural Development 2017}

declared plots decreased even by 1729. The growing of farms is likely to occur. It is purposeful to use for intensive farming fertile and reclaimed as well as unlimited by special conditions land areas. Extensive farming can be combined with unconventional farming methods.

3. After the analysis of abandoned land, it has been established that the area of abandoned land in Giedraičiai subdistrict reaches 296.91 hectares, the number of abandoned land parcels exceeds 800 . The abandonment of the land was influenced by prevailing sandy soils, high forest cover, prevailing wetlands, restrictions on special land and forest use conditions for surface water bodies. In order to reduce the abandoned land areas, it is favourable in these areas to grow forests, expand the area of meadows and natural pastures, apply organic farming and adapt areas for recreation.

4. The development of rural areas is regulated according to general planning documents and state targeted support measures. The aim is to create favourable living conditions in rural areas and to use land and other natural resources in the most rational way. After the preliminary land management solutions in the area of Giedraičiai subdistrict are prepared, it is planned to carry out rural development land management projects for the management of farm holdings as well as for the selection of farmhouse sites.

\section{REFERENCES}

1. Aleknavičius, A., Aleknavičius, P., Gurskienè, V. 2016. Kaimo plètros žemètvarkos projektų poreikis tvarkant ūkių teritorijas ir jų rengimo metodika. Žemès ūkio mokslai, No. 1, pp. 36-46 [In Lithuanian].

2. Aleknavičius, P., Stravinskienė, V. 2011. Žemès savybių įtaka žemės ūkio plètrai Lietuvoje. Kaimo raidos kryptys žiniu visuomeneje, pp. 188-198 [In Lithuanian].

3. Aleknavičius, P. 2014. Stabilių kraštovaizdžio objektų išdèstymo bei keitimo teisinis reglamentavimas. Darnaus vystymosi strategija ir praktika. Mokslo darbai, pp. 39-51 [In Lithuanian].

4. Bielinskas, V., Burinskienè, M. 2016. Apleistų miesto seniūnijų teritorijų rodiklių koreliacinè analizė. Vilniaus miesto atvejis. Mokslas - Lietuvos ateitis, No. 8(1), pp. 38-47 [In Lithuanian].

5. Jasaitis, J. 2014. Kaimiškujų vietovių strateginis valdymas. Metodinis leidinys savivaldybių darbuotojams. Vilnius, BMK leidykla [In Lithuanian].

6. Kuliešis G., Šalengaitė, D. 2010. Apleista žemė Lietuvoje: problemos, galimi sprendimo būdai. Management theory and studies for rural business and infrastructure development, Nr. 5 (24), pp. 116-127 [In Lithuanian].

7. Kuliešis, G., Šalengaitè, D., Kozlovskaja, A. 2011. Apleista žemè: problemos ir sprendimo būdai. Mokslo studija. Vilnius: Lietuvos agrarinès ekonomikos institutas [In Lithuanian].

8. Lietuvos Kaimo plètros 2014-2020 metu programa, patvirtinta Europos Komisijos 2015 m. vasario 13 d. sprendimu Nr. C(2015)842. Available at https://ec.europa.eu/agriculture/sites/agriculture/files/rural-development-2014-2020/countryfiles/lt/fulltext lt.pdf (Accessed on 02/09/2017) [In Lithuanian].

9. Lietuvos Respublikos Seimo nutarimas Nr. IX-1154 „Dèl Lietuvos Respublikos teritorijos bendrojo plano“. Available at https://www.e-tar.lt/portal/lt/legalAct/TAR.737EFE13DAE0 (Accessed on 10/09/2017). [In Lithuanian].

10. Lietuvos Respublikos teritorijų planavimo ịstatymo pakeitimo įstatymas, patvirtintas $2013 \mathrm{~m}$. birželio 27 d. Nr. XII-407. Available at https://www.e-tar.lt/portal/lt/legalAct/TAR.91F3BE482534 (Accessed on 02/09/2017). [In Lithuanian].

11. Lietuvos Respublikos Vyriausybės nutarimas Nr. 343 „Dẻl specialiujų žemès ir miško naudojimo sąlygų“. Available at https://www.e-tar.lt/portal/lt/legalAct/TAR.5C63BB64A956/WpVgKVURtk (Accessed on 02/09/2017). [In Lithuanian].

12. Lietuvos Respublikos žemès ịstatymas, patvirtintas $1994 \mathrm{~m}$. balandžio 26 d. Nr. I-446. Available at https://www.etar.1t/portal/lt/legalAct/TAR.CC10C5274343/dhDyLmuNNA (Accessed on 02/09/2017). [In Lithuanian].

13. Lietuvos Respublikos žemès fondas $2017 \mathrm{~m}$. sausio $1 \mathrm{~d}$. Nacionalinė žemės tarnyba prie Žemès ūkio ministerijos ir Valstybės imonè Registrų centras - Vilnius. [In Lithuanian].

14. Lietuvos Respublikos žemės ūkio, maisto ūkio ir kaimo plètros įstatymas, patvirtintas $2002 \mathrm{~m}$. birželio $25 \mathrm{~d}$. Nr. IX-987. Available at https://www.e-tar.lt/portal/lt/legalAct/TAR.80CA64E588A1 (Accessed on 02/09/2017). [In Lithuanian].

15. Melnikienè, R., Vidickienè, D., Gedminaitė - Raudonė, Ž., Ribašauskienė, E. 2011. Lietuvos regionų tipologijų pagal kaimiškumą tinkamumas regioninei politikai. Vadybos mokslas ir studijos - kaimo verslu ir ju infrastruktūros plètrai, No. 5 (29), pp. 126-134 [In Lithuaniain].

16. Molètų rajono Giedraičių seniūnijos plètros planas. 2015. Molètų rajono savivaldybès, Giedraičių seniūnija. [In Lithuanian].

17. Molètų rajono savivaldybè. 2017. Available at https://www.moletai.lt/index.php?399329907 (Accessed on 02/09/2017). [In Lithuanian].

18. Moravec, J., Zemeckis, R. 2007. Cross compliance and land abandonment. Deliverable D17 of the CC Network Project, SSPECT-2005-022727.

19. Ortega, V., Del Rio, A., Pointereau, P., Coulon, F., Girard, P., Lambotte, M., Stuczynski, T 2008. Analysis of Farmland Abandonment and hte Extent and Location of Agricultural Areas that are Actually or are inRisk to be Abandoned. Institute for Environment and Sustainability.

20. Ratkevičienè, E., Kocai, E. 2013. Socioekonominè Lietuvos kaimo būklè: ūkininkavimo aspektai. Available at http://www.su.lt/bylos/mokslo_leidiniai/Kaimas/2013_5ratkeviciene_kosai_2.pdf (Accessed on 02/09/2017) [In Lithuanian\}.

21. Rey Benayas, J., Martins, A., Nicolau, J.M., Schulz, J.J. 2007. Abandonment of agricultural land: an overview of drivers and consequences. Perspectives inAgriculture, Veterinary Science, Nutrition and Natural Recources. Available at htpp://www3.uah.es/josemrey/Reprints/ReyBenayasetal_Landabandonment_Perspektives_07 (Accessed on 10/09/2017). 
22. Ribokas, G. 2011. Apleistų žemių (dirvonų) problema retai apgyventose teritorijose. Kaimo raidos kryptys žinių visuomeneje, No. 2, pp. 298-307 [In Lithuanian].

23. Rico, E. C., Maseda, R.C. 2008. Land abandoment: Concept ande consequences. University of Santiago de Compostela. Journal of revista Galega de economia. Available at htpps;//www.researchgate.net/publication/286203048_Land_abandonment_Concept_and conse quences (Accessed on 02/09/2017).

24. Smith, P., Clark, H., Dong, H., Elsiddig, E.A., Haberl, H., Harper, R., House, J., Jafami, M. 2014. CHAPTER 11 - Agriculture, forestry and other land use (AFOLU). Climate Change : Mitigation of Climate Change. IPCC Working Group III Conribution to AR5. Cambridge University Press. Available at https://www.ipcc.ch/pdf/assessment-report/ar5/wg3/ipcc_wg_ar5_chapter11.pdf (accessed on 02/09/2017).

25. Valčiukienė, J., Atkocevičienė, V., Juknelienė, D. 2016. Lietuvos kaimiško agrarinio kraštovaizdžio ir jų tipų raidos apžvalga. Georafija ir edukacija, No.4, pp. 23-32 [In Lithuanian].

26. Vidickienè, D., Melnikienè, R. 2008. Paramos teikimo Lietuvos kaimo regionams kriterijų vertinimas. Vadybos mokslas ir studijos-kaimo verslu ir ju infrastruktūros pletrai, No. 1(12), pp. 176-182 [In Lithuanian].

27. Zabel, F., Putzenlechner, B., Mauser, W. 2014. Global Agricultural Land Resources - A High Resolution Suitability Evaluation and Its Perspectives until 2100 under Climate Change Conditions. Plos one 9 (9) e107522. Available at http://journals.plos.org/plosone/article?id-10.1371/journal.pone.0107522 (Accessed on 02/09/2017). 